УДК $616.724-036$

DOI10.11603/2311-9624.2016.3.6843

(СР. В. Кулінченко, В. Ф. Макєєв, Ю. О. Кінаш

Львівський національний медичний університет імені Данила Галицького

\title{
Аналіз варіантів поєднання різних форм скронево- нижньощелепних розладів за результатами обстеження хворих
}

Резюме. Робота присвячена підвищенню якості діагностики поєднаних форм скронево-нижньощелепних розладів (СНР) шляхом характеристики їх структури. У дослідженні визначено та здійснено аналіз варіантів поєднання різних форм СНР за результатами обстеження 114 хворих, вивчено особливості розподілу за статтю. Встановлено, що серед хворих із СНР частка осіб з поєднанням різних форм розладів склала $(51,8 \pm 4,7) \%$, $з$ них жінок - $(88,1 \pm 4,2) \%$, чоловіків - $(11,9 \pm 4,2) \%$, співвідношення кількості жінок до чоловіків склало 7,4:1,0. Серед хворих із поєднанням різних форм СНР частка варіанта «м’язовий розлад + внутрішній суглобовий розлад» склала $(37,3 \pm 6,3) \%$, «м'язовий розлад + артрит СНЩС» - $(33,9 \pm 6,2) \%$, інші варіанти поєднань розладів склали $(28,8 \pm 5,7) \%$. Отримані результати вказують на необхідність першочергового звертання уваги при диференційній діагностиці СНР, на виявлення ознак внутрішніх суглобових розладів та м’язових розладів, які поєднуються найчастіше.

Ключові слова: скронево-нижньощелепні розлади, поєднання форм розладів, структура розладів.

\section{Р. В. Кулинченко, В. Ф. Макеев, Ю. О. Кинаш}

Львовский национальный медицинский университет имени Данила Галицкого

\section{Анализ вариантов сочетания различных форм височно- нижнечелюстных расстройств по результатам обследования больных}

Резюме. Работа посвящена повышению качества диагностики сочетанных форм височно-нижнечелюстных расстройств (ВНР) путем характеристики их структуры. В исследовании проведен анализ вариантов сочетания различных форм ВНР по результатам обследования 114 больных, изучены особенности распределения по полу. Установлено, что среди больных с ВНР доля лиц с сочетанием разных форм расстройств составила $(51,8 \pm 4,7) \%$, из них женщин - $(88,1 \pm 4,2) \%$, мужчин - $(11,9 \pm 4,2)$ \%, соотношение количества женщин к мужчинам составило 7,4:1,0. Среди больных с сочетанными формами ВНР доля варианта «мышечное расстройство + внутреннее суставное расстройство» составила $(37,3 \pm 6,3) \%$, «мышечное расстройство + артрит ВНЧС» - $(33,9 \pm 6,2) \%$, другие варианты сочетаний расстройств составили $(28,8 \pm 5,7)$ \%. Полученные результаты указывают на необходимость первоочередного обращения внимания при дифференциальной диагностике ВНР, на обнаружение признаков внутренних суставных расстройств и мышечных расстройств, которые сочетаются наиболее часто.

Ключевые слова: височно-нижнечелюстные расстройства, сочетание форм расстройств, структура расстройств.

\author{
R. V. Kulinchenko, V. F. Makieyev, Yu. O. Kinash
}

Danylo Halytskyi Lviv National Medical University

\section{The analysis of a combination varieties of temporomandibular disorders different forms by results of patients' examination}

Summary. This paper is dedicated to the improvement of diagnosis quality of combined forms of temporomandibular disorders (TMD) by means of characteristic of their structure. In research, the combination varieties of TMD different forms were determined and analyzed due to the examination results of 114 patients and peculiarities of disorders' distribution taking into account the patients' gender were studied. The percentage of patients with a combination of different forms of TMD made up (51.8+4.7) \%, i.e., every second TMD pa- 
tient was subjected to the course of several different disorders simultaneously. Among them the percentage of women - $(88.1 \pm 4.2) \%$, men $-(11.9 \pm 4.2) \%$, the women/men ratio was equal to 7.4:1.0 correspondingly. Among the varieties of a combination of different forms of TMD, the percentage of the option «muscular disorder + TMJ internal disorder» was (37.3 \pm 6.3$) \%$, «muscular disorder + arthritis» - (33.9 \pm 6.2$) \%$, other options of combined disorders were $(28.8 \pm 5.7) \%$. The obtained results point to the necessity of primary consideration on the symptoms reveal of TMJ internal disorders and muscular disorders that combine most frequently, when performing differential diagnosis.

Key words: temporomandibular disorders, combination of disorders forms, structure of disorders.

Вступ. Проблема діагностики скроневонижньощелепних розладів (СНР) на сьогодні залишається актуальною, оскільки, за результатами клінічних досліджень різних авторів, від 40 до 89 \% населення відмічають ті чи інші симптоми порушення функції скронево-нижньощелепних суглобів (СНЩС) [1]. СНР виявляються як у дорослих, так і в дітей та підлітків, переважає в осіб жіночої статі [2-5]. Розлади можуть спричинятися різноманітними чинниками як травматичного, так і нетравматичного генезу, в тому числі ятрогенного [6-10]. Своєчасне виявлення СНР дозволяє запобігти розвитку тяжких патологічних змін у суглобі.

Значний інтерес викликають клінічні випадки, коли у хворих із СНР виявляють перебіг одночасно кількох різних форм розладів. У клінічній практиці особи з поєднаною патологією СНЩС становлять особливу групу хворих, які вимагають значно більшої уваги, більшої затрати часу при діагностиці, використання різноманітних додаткових променевих методів обстеження. Лікування таких пацієнтів $€$ завжди складнішим, комплексним та багатоетапним. Саме на цю групу хворих, на думку авторів [11], необхідно було б звернути більшу увагу і ширше висвітлити у наукових роботах.

Метою роботи було підвищення якості діагностики поєднаних форм скронево-нижньощелепних розладів шляхом характеристики ї структури. Завдання дослідження - визначити та здійснити аналіз варіантів поєднання різних форм скронево-нижньощелепних розладів серед хворих із СНР, дослідити особливості розподілу за статтю.
Матеріали і методи. Для вирішення поставленого завдання виділено групу осіб із поєднанням різних форм розладів серед 114 хворих, у яких було діагностовано СНР. 3 метою уточнення діагнозу та проведення диференційної діагностики як між різними формами скроневонижньощелепних розладів, так і з хворобами, маніфестація яких є схожа 3 симптоматикою CHР, усі особи з підозрою на СНР, окрім врахування особливостей клінічного обстеження [12], були скеровані на зонографічне обстеження та/ чи на ультрасонографію СНЩС та жувальних м'язів. За результатами клінічного обстеження визначали можливий перебіг СНР, використовуючи адаптоване для дослідження «СНР експрес-заключення» (Гамбурзький протокол) [13].

Частину хворих із підозрою на СНР було скеровано на консультації до фахівців інших спеціальностей, за рекомендацією і за участі яких хворі пізніше були направлені на томографічне обстеження, зокрема комп’ютерну томографію 3 можливістю програмної реконструкції тривимірного зображення скронево-нижньощелепних суглобів чи МРТ. Променеві методи обстеження застосовували згідно з розробленими алгоритмами диференційної діагностики скронево-нижньощелепних розладів $[14,15]$.

Результати досліджень та їх обговорення. Серед 114 хворих із різними формами скронево-нижньощелепних розладів жінки склали $85,96 \%$, чоловіки - 14,04 \% (табл. 1).

При обстеженні виявили випадки, коли у одного хворого було два чи три різних розлади одночасно (табл. 2). У 16 чоловіків виявили 25 розладів, у 98 жінок - 155 СНР.

таблищя 1. Частка осіб жіночої та чоловічої статей серед обстежених хворих із скронево-нижньощелепними розладами

\begin{tabular}{|l|c|c|c|}
\hline \multicolumn{1}{|c|}{ Стать } & Кількість осіб & $\begin{array}{c}\text { Частка осіб, } \\
\text { р } \pm \text { mp (\%) }\end{array}$ & $\begin{array}{c}\text { Співвідношення кількості } \\
\text { жінок до чоловіків }\end{array}$ \\
\hline Чоловіча & 16 & $14,04 \pm 3,25$ & \multirow{2}{*}{$6,1: 1,0$} \\
\hline Жіноча & 98 & $85,96 \pm 3,25$ & \\
\hline Разом & 114 & 100 & \\
\hline
\end{tabular}


Таблищя 2. Поділ хворих за статтю і за кількістю різних скронево-нижньощелепних розладів, виявлених одночасно в одного хворого

\begin{tabular}{|c|c|c|c|c|}
\hline \multirow{2}{*}{$\begin{array}{c}\text { Кількість виявлених СНР } \\
\text { у хворого }\end{array}$} & \multicolumn{3}{|c|}{ Кількість хворих } & \multirow{2}{*}{ Кількість СНР у хворих } \\
\cline { 2 - 4 } & чоловіки & жінки & разом & 55 \\
\hline 1 & 9 & 46 & 55 & 104 \\
\hline 2 & 5 & 47 & 52 & 21 \\
\hline 3 & 2 & 5 & 7 & 180 \\
\hline Разом & 16 & 98 & 114 & \\
\hline
\end{tabular}

Таким чином, у 59 хворих $(51,75 \pm 4,68) \%$ виявили поєднання м'язових і різних суглобових розладів загальною кількістю 125. Серед цих осіб жінки склали 88,14 \%, чоловіки - 11,86 \% (табл. 3). Серед означених хворих виявили сім варіантів поєднання різних форм СНР (перебіг одночасно двох чи трьох різних розладів з одного чи $з$ двох боків) (табл. 4).

таблиця 3. Частка осіб жіночої та чоловічої статей серед хворих із поєднанням різних форм скронево-нижньощелепних розладів

\begin{tabular}{|l|c|c|c|}
\hline Стать & Кількість осіб & $\begin{array}{c}\text { Частка осіб, } \\
\mathrm{p} \pm \mathrm{mp}(\%)\end{array}$ & $\begin{array}{c}\text { Співвідношення кількості жінок до } \\
\text { чоловіків }\end{array}$ \\
\cline { 1 - 3 } Чоловіча & 7 & $11,86 \pm 4,21$ & \multirow{2}{*}{$7,4: 1,0$} \\
\cline { 1 - 3 } Жіноча & 52 & $88,14 \pm 4,21$ & \\
\cline { 1 - 3 } Разом & 59 & 100 & \\
\hline
\end{tabular}

таблищя 4. Варіанти поєднання різних форм скронево-нижньощелепних розладів

\begin{tabular}{|c|c|c|c|}
\hline $\begin{array}{c}\text { Варіанти поєднання скронево- } \\
\text { нижньощелепних розладів }\end{array}$ & Кількість осіб & $\begin{array}{c}\text { Частка осіб, } \\
\mathrm{p} \pm \mathrm{mp}(\%)\end{array}$ & Кількість СНР \\
\hline М’язовий СНР + ВСР & 22 & $37,29 \pm 6,30$ & 44 \\
\hline М’язовий СНР + артрит СНЩС & 20 & $33,90 \pm 6,16$ & 40 \\
\hline М’язовий СНР + вивих СНЩС & 5 & $8,47 \pm 3,63$ & 10 \\
\hline ВСР + вивих СНЩС & 4 & $6,78 \pm 3,27$ & 8 \\
\hline ВСР + артроз СНЩС & 1 & $1,70 \pm 1,68$ & 2 \\
\hline М'язовий СНР + ВСР + вивих СНЩС & 5 & $8,47 \pm 3,63$ & 15 \\
\hline М'язовий СНР + ВСР + артрит СНЩС & 2 & $3,39 \pm 2,36$ & 6 \\
\hline Разом & 59 & 100 & 125 \\
\hline
\end{tabular}

Примітка. ВСР - внутрішній суглобовий розлад.

Висновки. У кожного другого пацієнта $(51,8 \pm 4,7)$ \% спостерігалась одночасна маніфестація декількох форм СНР, серед яких поєднання «м'язовий розлад + внутрішній суглобовий розлад» склало $(37,3 \pm 6,3) \%$, «м’язовий розлад + артрит СНщС» - $(33,9 \pm 6,2) \%$, інші варіанти поєднань - $(28,8 \pm 5,7) \%$. Серед означених осіб жінки склали $(88,1 \pm 4,2) \%$, чоловіки - $(11,9 \pm 4,2)$

\section{Список літератури}

1. Воловар О. С. Можливості променевої діагностики патології скронево-нижньощелепного суглоба (огляд) / О. С. Воловар, В. О. Маланчук, О. І. Жуковцева // Укр. мед. часопис. - 2010. - № 3. - С. 90-94.
\%, співвідношення кількості жінок до чоловіків 7,4:1,0. Отримані результати вказують на необхідність першочергового звертання уваги, при диференційній діагностиці СНР, на виявлення ознак внутрішніх суглобових розладів та м'язових розладів, які поєднуються найчастіше.

2. Prevalence and association of headaches, temporomandibular joint disorders, and occlusal interferences / M. Troeltzsch, M. Troeltzsch, R. J. Cronin [et al.] // J. Prosthet. Dent. - 2011. - Vol. 105, № 6. P. 410-417. 
3. Sex-specific differences in patients with temporomandibular disorders / M. Schmid-Schwap, M. Bristela, M. Kundi, E. Piehslinger // J. Orofac. Pain. 2013. - Vol. 27, № 1. - P. 42-50.

4. Signs and symptoms of temporomandibular joint disorders in Caucasian children and adolescents / S. Tecco, V. Crincoli, B. Di Bisceqlie [et al.] // Cranio. 2011. - Vol. 29, № 1. - P. 71-79.

5. Кулінченко Р. В. Клініко-морфологічна характеристика скронево-нижньощелепних суглобів за наявності дефектів зубних рядів : автореф. дис. на здобуття наук. ступеня канд. мед. наук : спец. 14.01.22 «Стоматологія» / Р. В. Кулінченко. - Львів, 2016. - 20 с. 6. Макєєв В. Ф. Сучасні погляди на етіологію і патогенез дисфункцій скронево-нижньощелепних суглобів : огляд літератури / В. Ф. Макєєв, Ю. О. Риберт, Н. С. Магера // Новини стоматології. - 2014. - № 1. C. 14-18.

7. Наслідки видалення третіх молярів при ортодонтичному лікуванні аномалій прикусу / д. С. Аветіков, І. В. Яценко, О. О. Розколупа [та ін.] // Вісник проблем біології і медицини. - 2015. - Вип. 2, т. 2. C. 12-13.

8. Рыбалов О. В. Стоматологическая манипуляция - одна из причин развития анатомофункциональных нарушений компонентов височно-нижнечелюстного сустава / О. В. Рыбалов, П. А. Москаленко, О. И. Яценко // Вісн. стоматології. 2008. -№ 1. - С. 151-152.

9. Телішевська О. Д. Невчасно діагностовані переломи суглобових відростків нижньої щелепи як причина скронево-нижньощелепних розладів /
О. Д. Телішевська // Новини стоматології. - 2015. № 2. - C. 40-44.

10. Oral and Maxillofacial Pathology. - 2nd ed. / B. W. Neville, D. D. Damm, C. M. Allen, J. E. Bouquot. Philadelphia ; London ; New York ; St. Louis ; Sydney ; Toronto : W. B. Saunders Company, 2001. - 768 p.

11. Manfredini D. Current concepts on temporomandibular disorders / D. Manfredini. - London; Berlin ; Chicago : Quintessence publishing Co. Ltd, 2010. $498 \mathrm{p}$.

12. Макєєв В. Ф. Особливості обстеження хворих на скронево-нижньощелепні розлади / В. Ф. Макєєв, Р. В. Кулінченко // Український стоматологічний альманах. - 2006. - № 1. - С. 53-61.

13. Особливості диференційованої діагностики скронево-нижньощелепних розладів за клінічними і рентгенологічними ознаками / В. Ф. Макєєв, У. Д. Телішевська, Р. В. Кулінченко, М. І. Заверуха // Український стоматологічний альманах. - 2011. № 1. - С. 69-74.

14. Критерії диференційної діагностики скроневонижньощелепних розладів. Алгоритми додаткового дослідження скронево-нижньощелепних суглобів методами променевої діагностики / В. Ф. Макєєв, У. Д. Телішевська, Р. В. Кулінченко, О. Д. Телішевська // Львівський медичний часопис. = Acta Medica Leopoliensia. - 2012. - T. 18, № 1. - C. 38-42.

15. Обгрунтування послідовності проведення клінічного функціонального аналізу стану зубощелепної системи у пацієнтів 3 підозрою на скронево-нижньощелепні розлади / В. Ф. Макєєв, У. Д. Телішевська, Р. В. Кулінченко, О. Д. Телішевська // Вісник проблем біології і медицини. - 2014. T. 1, № 2. - C. 233-238. 